American Journal of Applied Sciences 7 (4): 603-608, 2010

ISSN 1546-9239

(C) 2010Science Publications

\title{
Socio-Demography Factors that Influence Youth Attitude Towards Contract Farming
}

\author{
Jeffrey Lawrence D’Silva, Hayrol Azril Mohamed Shaffril, \\ Jegak Uli and Bahaman Abu Samah \\ Laboratory of Rural Advancement and Agricultural Extension, \\ Institute for Social Science Studies, University Putra Malaysia, Malaysia
}

\begin{abstract}
Problem statement: Malaysia is one of the developing countries that rely on agriculture to boost its economy sector. This can be proved through The Ninth Malaysia Plan where agriculture is planned to be the third income generator of the country. Contract farming is one of the potential agriculture activities that proffers propel maximization of production and enhancing economic and social conditions among the farming communities. This innovative and economic viable farming opportunity indeed depends on the commitment of youth since they are the pillar to the sustainability of agriculture. However, do youth in Malaysia have a positive attitude towards contract farming? Approach: This study is a quantitative study, using a pre tested and developed questionnaire. This study inspected the attitude of Malaysian youths toward contract farming and socio-demography factors that affect it. A sample random sampling were performed where a total of 400 undergraduates were selected to be the respondents of the study. The data were analyzed using PASW software. Results: Results gained depicted that youths have a positive attitude towards contract farming. Moreover, from the independent t-test and ANOVA test done, it can be concluded that information regarding contract farming, type of course taken and university where the students study play a major role in influencing their attitude towards contract farming. Conclusion/Recommendations: From the results gained it can be concluded that information, course taken and universities where they learn can influence youth acceptance towards contract farming. It can be noted that specific course on contract farming can be established within selected universities in order to expose contract farming to the youth. It was recommended that a specific study on the role of universities in creating a better attitude among youth should be conducted.
\end{abstract}

Key words: Socio-demography factors, attitude, youth, contract farming

\section{INTRODUCTION}

Malaysia is aiming to be a developed country in 2020. To achieve this, preparation on all aspects have been intensified and this includes the agriculture sector. Agriculture nowadays has already become a major mechanism to boost the economic activities of most part of the world including Malaysia. As been stated by the Prime Minister of Malaysia agriculture will be one of the major focuses in 2010. The productivity of agriculture is expected to be enhanced during 2010. The export value will reach USD216 million while the import value of agriculture industry in Malaysia is expected to be reduced from USD4.53 million to just USD4.20 million. These figures for sure will offer profit to the community and perhaps it can play a pivotal role to solve problems such as poverty and unemployment. Agriculture offers a lot of attractive activities and businesses. The most popular agriculture activities are fisheries and agro-based industry. The rise of new contract farming activities such as leech rearing, worms rearing, herbs and mushroom have indeed attracted huge interests from the public.

Youth without doubt is the backbone of the community. They are the future leaders of the world. But who are youth? The United Nation defined those whose age between 15-24 years old can be categorized as youth. The Malaysian Youth Council (2007) has other view, they emphasized that those whose age ranged between 15-40 years old can be considered as youth. Based on the official website of the Malaysia Institute for Youth Development Research Centre, in

Corresponding Author: Jeffrey Lawrence D’Silva, Laboratory of Rural Advancement and Agriculture Extension, Institute for Social Science Studies, University Putra Malaysia, 43400 Serdang, Selangor Darul Ehsan, Malaysia 
2008, the number of youth constituted almost half of Malaysian citizens and this has contributed vastly to a massive unemployment rate among youth as the latest statistics show that the current rate of unemployment among youth in Malaysia is $4 \%$.

One of the modern agriculture methods that can be undertaken to overcome the rate of unemployment is to encourage youth participation in contract farming. Generally, contract farming involves agreement between two parties, farmers and contractors for the production and supply of agricultural products based on a forward agreement usually at a predetermined price. Based on the contract, the purchaser can determine the quantity of production they want through input and technical advices and guidance for the crop cultivation. On the farmer side, they must ensure the demand of the purchaser on the quantity must be produced within the quality standards as required by the purchaser and the firms support, in turn, the farmer production and also purchase the produce. The contract between the purchaser and the farmers covers three areas viz., market (grower and buyer agree for future sale and purchase), resource (buyer agrees to supply inputs and technical advice) and management specifications (grower agrees to follow the recommended practices for the crop cultivation) (Erappa, 2006).

There are a number of issues that need to be considered to encourage youth's participation in contract farming. One of the driving factors is youth's attitude towards contract farming. In general, attitudes are defined as an evaluative disposition based upon cognitions, affective reactions, behavioral intentions and past behaviors and it describes general individual feelings of favor or disfavor toward a specific behavior. In other words, attitudes refer to an individual's degree of like or dislike for an item. Attitudes are generally depicting the positive or negative views of a person, place, thing or event. This is often defined as the attitude object. People can have conflict or ambivalent toward an object, meaning that they simultaneously possess both positive and negative attitudes toward the item in question (Breckler and Wiggins, 1992).

The issue at stake now is: what is youth's attitude towards contract farming in Malaysia. If Malaysia were to largely focus on agriculture to boost their economy sector, does the public especially the youth have a good attitude towards it? Attitude indeed can play a major role in motivating people to be part of agriculture community but what are the factors that affect it? Thus, this query become the main task of this study, which is to know the level of attitude of youth in Peninsular Malaysia and to know the socio-demography factors that affect it.
Demography factors are constructs that affect attitude towards contract farming. However, there were only a few studies that looked into the impact of demographic factors on attitude towards contract farming in Malaysia. Among demographic variables that had been studied were gender, age, income, locality and ethnicity. In terms of relationship between gender and attitude towards contract farming, previous study by Konavalchuk et al. (2008) reported that gender did not have a significant impact on work performance. However, a study done by Gidarakou (1999) noted that women were found to have negative attitude towards contract farming compared to men. Moreover, based on the existing literature, there are some inconsistencies found where a study done by Strohm and Hoeffler (2006) found that men have a better attitude towards contract farming. This probably occurred perhaps due to men being more exposed to agriculture activities than women.

A study by Akila and Chander (2009) showed that age does not affect attitude towards contract farming, thus it contradicts with what have been revealed by Toma and Mathijs (2007), who noted that age differences could be also an important determinant for attitude towards contract farming. This is consistent with a study completed by Irshad (2007) who found that there were significant differences between age groups concerning attitude towards contract farming. Conversely, what have been found by Irshad (2007) is opposed by a study done by Magnusson et al. (2001).

How about income? Can this factor influence youth attitude towards contract farming? Based on the literature analysis done, some inconsistencies were identified. Stephenson and Lev (2004) found that income is not a major determinant in creating a better attitude towards agriculture activities while a study completed by Hyttia and Kola (2006) found a totally different view. Hyttia and Kola (2006) stressed that income is a major factor that will influence people's attitude towards agriculture activities. Generally, lower income people tend to choose agriculture activity as their main money generating activity or as a side income.

Rural people are always associated with agriculture activities including contract farming. Lenihan et al. (2009) stressed that these positive attitude of the rural community may be particularly relevant in rural locations due to their process of undergoing rapid transformation of the agricultural system, economic base and related land uses. Sharp and Smith (2003) have other view, they noted through their study that there is a negative and significant relationship between rural and urban communities towards agriculture activities. The inconsistencies found in the literature analysis drive us to 
a need to conduct a study pertinent to the sociodemography factors that influence the attitude of youth towards contract farming in Malaysia.

\section{MATERIALS AND METHODS}

A total of 400 respondents from four universities were selected as the respondents for this study. There four selected universities/college were University Putra Malaysia (representing central zone), University Malaysia Terengganu (representing east coast zone), Northern University of Malaysia (representing northern zone) and Rubber Industry and Smallholders Development Authority (RISDA) College (representing southern zone). From these four institutions, a total of 400 respondents were chosen. This study is based on quantitative method. To collect the required data, a pretested and developed questionnaire was used. Self- administered method was employed where basic explanation and instructions were given to the respondents before they answer the questions. The data collection took two months to be completed. To fulfill the objectives, descriptive analyses such as frequency, percentage, mean and standard deviation were employed while inferential analyses such as Independent t-test and ANOVA were performed to inspect any significant different that could occur between the dependent and independent variables. The dependent variable for this study is attitude towards contract farming while the independent variables in this study are the selected sociodemography factors.

\section{RESULTS AND DISCUSSION}

Before we go into the main objective of the study, it is better for us to know the respondents studied.

\begin{tabular}{|c|c|c|c|c|}
\hline Variables & Frequency & Percentage & Mean & Standard deviation \\
\hline \multicolumn{5}{|l|}{ Gender } \\
\hline Male & 117 & 29.2 & & \\
\hline Female & 283 & 70.8 & & \\
\hline \multicolumn{5}{|l|}{ Ethnic } \\
\hline Malay & 360 & 90.0 & & \\
\hline Chinese & 15 & 3.8 & & \\
\hline Indian & 14 & 3.5 & & \\
\hline Others & 11 & 2.7 & & \\
\hline Age & & & 20.78 & 1.53 \\
\hline $18-19$ years & 111 & 27.8 & & \\
\hline 20-21 years & 161 & 40.2 & & \\
\hline 22-24 years & 128 & 32.0 & & \\
\hline \multicolumn{5}{|l|}{ Zone (location of university/college) } \\
\hline UUM & 100 & 25.0 & & \\
\hline UPM & 100 & 25.0 & & \\
\hline UMT & 100 & 25.0 & & \\
\hline RISDA College & 100 & 25.0 & & \\
\hline \multicolumn{5}{|l|}{ Level of recent education received } \\
\hline Degree & 300 & 75.0 & & \\
\hline Diploma & 100 & 25.0 & & \\
\hline Monthly expenditure (value in ring & & & 395.85 & 217.18 \\
\hline$<200$ & 57 & 14.2 & & \\
\hline $201-300$ & 102 & 25.5 & & \\
\hline $301-400$ & 127 & 31.8 & & \\
\hline$>401$ & 114 & 21.5 & & \\
\hline \multicolumn{5}{|l|}{ Courses taken } \\
\hline Agriculture & 200 & 50.0 & & \\
\hline Economic & 100 & 25.0 & & \\
\hline Others & 100 & 25.0 & & \\
\hline \multicolumn{5}{|l|}{ Locality } \\
\hline Rural & 162 & 40.5 & & \\
\hline Urban & 238 & 59.5 & & \\
\hline \multicolumn{5}{|l|}{ Family background ( $\mathrm{n}=381$ ) } \\
\hline Have agriculture background & 79 & 19.8 & & \\
\hline Do not have agriculture background & 302 & 75.5 & & \\
\hline \multicolumn{5}{|l|}{ Received information regarding } \\
\hline \multicolumn{5}{|l|}{ Contract farming } \\
\hline Yes & 219 & 54.8 & & \\
\hline No & 181 & 45.2 & & \\
\hline
\end{tabular}


Based on the results presented in Table 1, it can be seen that a large majority of the respondents $(70.8 \%)$ are female. Result gained is parallel with the current situation in Malaysia's higher learning institutions where females constitute the larger number of future graduates compared to male students. A total of $90.0 \%$ respondents were Malay while slightly more than two fifth of the respondents (40.2\%) age between 20-21 years. A large majority of the respondents are taking degree course $(75.0 \%)$ and their family has no agriculture background (75.5\%). Based on the data gained, it was found that almost one third of the respondents (31.8\%) spent RM300-RM400 a month. A total of $50.0 \%$ of the respondents take agriculture course compared to only $25.0 \%$ for economy and other courses. More than half of the respondents (59.5\%) live in urban area and have received no information regarding contract farming.

In this part, we will look into the next objective which is to reveal the respondents attitude toward contract farming. As portrayed in Table 2, it can be concluded that majority of respondents have a high positive attitude toward contract farming whereby it accounted for $69.4 \%$ of the respondents. It was found that only $0.8 \%$ of the respondents have a low attitude toward contract farming. This is a good indicator for the future of agriculture in our country as the respondents believe that innovative agricultural methods will prompt them to embark in agriculture activities.

Is there any influence that are brought by these four factors namely contract farming information, gender, locality and agriculture background on youth's attitude towards contract farming? Table 3 has provided the answers for this question. Independent t-test was conducted in order to know any differences.

Based on the independent t-test performed, it can be concluded that there is a significant difference on attitude towards contract farming for those who received information regarding contract farming $(\mathrm{M}=7.47, \mathrm{SD}=$ 1.36) and those who did not receive the information $(\mathrm{M}=7.17, \mathrm{SD}=1.37$; $(400)=-0.2 .193, \mathrm{p}=0.029)$. Information can play a major role in determining positive attitude towards something as stressed by Strohm and Hoeffler (2006). There is a possibility those who are exposed more to contract farming information will have positive attitude compared to those who do not receive the contract farming information.

Gender differences have become a major thing in almost every issue and this includes contract farming. Do males have a better attitude toward contract farming or otherwise? Results presented in Table 3 inform us that there is no significant difference found on attitude towards contract farming between male and female respondents in their attitude towards contract farming [based on male $(\mathrm{M}=7.47, \mathrm{SD}=1.37)$ and for female $(\mathrm{M}=7.28, \mathrm{SD}=1.38$; $\mathrm{t}(400)=1.267, \mathrm{p}=.206)]$. There is a possibility that both male and female students have a positive attitude toward contract farming. Results gained here surprisingly contradicts with what have been clarified by Haugen and Brandth (1994) and Haugen (2008) whereby they noted that females have less positive attitude compared to males. They even emphasized that in some cases females and agriculture can be considered as diverse groups.

Vera-Tascona et al. (2008) through his research found those who live in rural area have better attitude towards contract farming compared to their counterpart. Can the similar situation occur in Malaysia? Results depicted in Table 2 concluded that $(\mathrm{M}=7.28, \mathrm{SD}=$ 1.45) for urban respondents and $(\mathrm{M}=7.37, \mathrm{SD}=1.32$; $t(400)=-0.673, p=0.501)$ for rural respondents, it can be clarified that there is no significant difference in attitude towards contract farming between urban and rural respondents, thus it contradicts with what have been proved by Vera-Tascona et al. (2008).

Based on the independent t-test done, it can be noted that there is no significant difference between those who have family agriculture background and those who do not have. This is based on ( $\mathrm{M}=7.27$, $\mathrm{SD}=1.17)$ for those who have agriculture background and $(\mathrm{M}=7.34, \mathrm{SD}=1.41 ; \mathrm{t}(400)=-0.418, \mathrm{p}=0.676)$ for those who do not have family agriculture background, thus it proved that family background has no influence on youths attitude towards contract farming.

Table 2: Distribution of respondent's attitude toward contract farming

\begin{tabular}{lclll}
\hline Factors & Frequency & Percentage & Mean & SD \\
\hline Attitude & & & 7.33 & 1.38 \\
Low (1.0-3.33) & 3 & 0.8 .0 & & \\
Moderate (3.34-6.67) & 119 & 29.8 & & \\
High (6.68-10.0) & 278 & 69.4 & & \\
\hline
\end{tabular}

Table 3: Comparison between selected demographic factors and attitude towards contract farming using independent t-test

\begin{tabular}{|c|c|c|c|c|c|}
\hline Variables & $n$ & Mean & SD & $\mathrm{t}$ & $p$ \\
\hline \multirow{2}{*}{\multicolumn{4}{|c|}{$\begin{array}{l}\text { Received contract } \\
\text { Farming information }\end{array}$}} & -2.193 & 0.029 \\
\hline & & & & & \\
\hline Yes & 219 & 7.47 & 1.36 & & \\
\hline No & 181 & 7.17 & 1.37 & & \\
\hline Gender & & & & 1.267 & 0.206 \\
\hline Male & 117 & 7.47 & 1.37 & & \\
\hline Female & 283 & 7.28 & 1.38 & & \\
\hline Locality & & & & -0.673 & 0.501 \\
\hline Urban & 162 & 7.28 & 1.45 & & \\
\hline Rural & 238 & 7.37 & 1.32 & & \\
\hline $\begin{array}{l}\text { Agriculture } \\
\text { background }(n=381)\end{array}$ & & & & -0.418 & 0.676 \\
\hline Yes & 79 & 7.27 & 1.17 & & \\
\hline No & 302 & 7.34 & 1.410 & & \\
\hline
\end{tabular}


Am. J. Applied Sci., 7 (4): 603-608, 2010

To achieve one of the objectives of this study, which is to know influence of course taken, university where the respondents studied, age and monthly expenditure on attitude towards contract farming, ANOVA test was utilized.

For further analyses, ANOVA test was performed to reveal any differences that may occur between attitude towards contract farming and course taken, place where they learn, age and monthly expenditure. Based on the data gained, course taken do have influence on youth attitude towards contract farming based on $F=(4,400)=11.192, p=0.0001$. Tukey Post Hoc Multiple Comparison depicted a statistically significant difference in the mean test score for the agriculture course and economy course and other courses but not for economy course and others course. A further analysis of the mean score based on posthoc comparisons using Tukey test noted that the students who are taking agriculture course recorded significantly higher mean score on attitude towards contract farming $(\mathrm{M}=7.66, \mathrm{SD}=1.32)$ than economy course $(\mathrm{M}=7.09$, $\mathrm{SD}=1.28)$ and other courses $(\mathrm{M}=6.97, \mathrm{SD}=1.43)$.

How about places where the respondents learn? Does the university or college where the students learn can affect their attitude towards contract farming? Table 4 has the answer. Based on the $F=(4,400)=$ $10.616, \mathrm{p}=0.0001$, there is a significant difference on attitude towards contract farming between the four groups studied. Status of agriculture university may lead to higher mean score for attitude towards contract farming for UPM students $(\mathrm{M}=7.87, \mathrm{SD}=1.28)$. A further analysis of the mean score based on post-hoc comparisons using Tukey test noted that the respondents from UPM recorded statistically significantly higher mean scores on attitude toward contract farming $(\mathrm{M}=7.87, \mathrm{SD}=1.28)$ than respondents from RISDA college $(\mathrm{M}=7.48, \mathrm{SD}=1.26)$ and respondents from UUM $(\mathrm{M}=7.08, \mathrm{SD}=1.28)$ and those studying in UMT $(\mathrm{M}=6.90, \mathrm{SD}=1.48)$.

Can the age of the respondents influence their attitude towards contract farming? For age, the highest mean score recorded was for age group of 22-24 years old $(\mathrm{M}=7.44, \mathrm{SD}=1.28)$, followed by age group of $18-19$ years $(\mathrm{M}=7.41, \mathrm{SD}=1.27)$ and the lowest mean score recorded by those from age group of 20-21 years $(\mathrm{M}=7.19, \mathrm{SD}=1.51)$. Based on $\mathrm{F}(3,400)=1.444, \mathrm{p}$ $=0.237$, there is no significant differences between the three age groups that were involved in this study. There is some inconsistencies found here when Van Bulow and Sorensen (1993), noted that age is among the major factors that will drive community to have a positive attitude towards contract farming.
Table 4: Comparison in selected socio-demographic factors and attitude towards contract farming using ANOVA $(n=450)$

\begin{tabular}{llllll}
\hline & $\mathrm{n}$ & Mean & $\mathrm{SD}$ & $\mathrm{F}$ & $\mathrm{p}$ \\
\hline Courses taken & & & & 11.194 & 0.0001 \\
Agriculture & 194 & 7.66 & 1.32 & & \\
Economy & 100 & 7.09 & 1.28 & & \\
Others & 106 & 6.97 & 1.43 & & \\
Universities/college & & & & 10.616 & 0.0001 \\
UPM & 100 & 7.87 & 1.28 & & \\
RISDA college & 100 & 7.48 & 1.26 & & \\
UUM & 100 & 7.08 & 1.28 & & \\
UMT & 100 & 6.90 & 1.48 & & \\
Age & & & & 1.444 & 0.237 \\
18-19 years & 111 & 7.41 & 1.27 & & \\
$20-21$ years & 161 & 7.19 & 1.51 & & \\
$22-24$ years & 128 & 7.44 & 1.28 & & \\
Monthly expenditure (value & & & & 0.925 & 0.429 \\
in ringgit Malaysia) & & & & & \\
$<200$ & 57 & 7.53 & 1.31 & & \\
201-300 & 102 & 7.43 & 1.23 & & \\
$301-400$ & 127 & 7.25 & 1.46 & & \\
$>401$ & 114 & 7.24 & 1.44 & & \\
\hline
\end{tabular}

This study was also interested to know whether financial power has influence on attitude towards contract farming, is this finding of this study can be consistent with studies by Cao et al. (2009) who stressed that net income is among the key factors that will influence attitude. Table 4 concludes that $\mathrm{F}(4,400)$ $=0.925, \mathrm{p}=0.429$, thus reveals that there is no significant difference on attitude towards contract farming between the four groups studied. Results gained here contradict with a study completed by Akila and Chander (2009).

\section{CONCLUSION}

This study illustrates the empirical research on the impact of socio-demographic factors on youth's attitude towards contract farming. Results from this study depict that information concerning contract farming, type of course taken and universities where the students study play a significant part in influencing youth's attitude toward contract farming.

Doubtlessly, information contributes much to gearing youths to participate actively in innovative farming methods such as contract farming. Information would be able to facilitate knowledge regarding new agricultural and rural business opportunities and ways and means to optimize farm production. This would ensure in effective farm management and efficient knowledge transfer that would boost youth to remain competitive and vibrant entrepreneurs.

Unsurprisingly, the type of course taken would also influence youth's involvement in contract farming. The early exposure towards agriculture enables youth to have an early exposure towards farming and they would be able to endeavor problems faced in farming using sound solutions rather than approaches based on invalid assumptions. Eventually, this would help them to build 
positive attitude toward farming and able to withstand all obstacles experienced in their farming career.

The place of study too plays a pivotal role in ensuring youths possess the right attitude towards entailing in contract farming. If a particular tertiary institution puts great emphasis on getting their students to partake in farming, this will help to generate the minds of the youths to pursue on agriculture once they have graduated. Besides, universities that are able to motivate their budding students to join in farming activities would eventually see that their students make a real difference to farming on an enterprising and a regional scale.

It is recommended that more studies should be carried out to examine the complexities associated with youth's participation in farming and special attention should be given to identify the role of universities in strategizing specific agricultural courses that would boost youth to possess a better attitude towards active involvement in farming.

\section{REFERENCES}

Akila, N. and M.F. Chander, 2009. Attitude towards utilization of draught bullocks in Indian agriculture. Lives. Res. Rural Dev., 21: 1-5.

Breckler, S.J. and E.C. Wiggins, 1992. On Defining Attitude and Attitude Theory: Once More with Feeling. In: Attitude Structure and Function, Pratkanis, A.R., S.J. Breckler and A.C. Greenwald (Eds.). Erlbaum, Hillsdale, NJ., ISBN: 0805803238, pp: 407-427.

Cao, S., L. Chen and Z. Liu, 2009. An investigation of Chinese attitudes towards the environment: Case studies using the grain for the green project. AMBIO: J. Hum. Environ., 38: 55-64. DOI: 10.1579/0044-7447-38.1.55

Erappa, S., 2006. Contract farming in Karnataka: A boon or a bane? Research report 9/ADRT113. Agricultural Development and Rural Transformation Centre, Institute for Social and Economic Change, Bangalore, India. http://www.isec.ac.in/CONTRACT\%20FARMING \%20FINAL\%20REPORT.pdf

Gidarakou, I., 1999. Young women's attitude towards agriculture and women's new roles in the Greek countryside: The first approach. Rural Studies., 15: 147-158. DOI: 10.1016/S0743-0167(98)00054-0

Haugen, M.S. and B. Brandth, 1994. Gender difference in modern agriculture: The case of female farmers in Norway. Gender Soc., 8: 206-229. DOI: 10.1177/089124394008002005

Hyttia, N. and J. Kola, 2006. Finish citizens' attitude towards multifunctional agriculture. EconPapers http://econpapers.repec.org/paper/agseaae05/24736 .htm
Haugen, M.S., 2008. Female farmers in Norwegian agriculture from traditional farm women to professional farmers. J. Sociol. Ruralis, 30: 197-209. DOI: 10.1111/j.1467-9523.1990.tb00409

Irshad, F.M., 2007. The Agricultural Community-50 years of Malaysian Agriculture. Malaysian Agriculture: Transformational Issues, Challenges and Direction. Penerbit Universiti Putra Malaysia, Serdang, Selangor, ISBN: 978-967-5026-14-0, pp: 826.

Konavalchuk, V., G.D. Hanson and A.E. Luloff, 2008. Layered community support for sustainable dairy farming. J. Extention, 46: 1-14. http://www.joe.org/joe/2008december/a3.php

Lenihan, M.H., K.J. Brasier and R.C. Stedman, 2009. Perception of agriculture's multifunctional role among rural Pennsylvanians. Res. Rural Sociol. Dev., 14: 127-149. DOI: 10.1108/S10571922(2009)0000014008

Magnusson, M.K., A. Arvola, U.K. Koivisto Hursti, L. Alberg and P.O. Sjoden, 2001. Attitudes towards organic foods among Swedish consumers. British Food J., 103: 209-227. DOI: 10.1108/00070700110386755

Malaysia Youth Council, 2007. Skim Belia Tani. http://www.belia.org.my/index.php?option=com_c ontent\&task=view\&id $=100$

Sharp, J.S. and M.B. Smith, 2003. Social and capital farming at the rural-urban interface: The importance of non-farmers and farmers relations. Agric. Syst., 76: 913-927. DOI: 10. 1016/S08832927(02)00083-5.

Stephenson, G. and L. Lev, 2004. Common support for local agriculture in two contrasting Oregon communities. Renew. Agric. Food Syst., 19: 210-217. DOI: 10.1079/RAFS200481

Strohm, K. and H. Hoeffler, 2006. Contract farming in Kenya: Theory evidence form selected value chains and implications for development cooperation. http://www.unileipzig.de/ afrika/index.php?option=com_docman \&task=doc_view\&gid=128\&Itemid=83\&lang=del

Toma, L. and E. Mathijs, 2007. Environmental risk perception, environmental concern and propensity to participate in organic farming programmes. Environ. Manage., 83: 145-157. DOI: 10.1016/j.jenvman.2006.02.004

Van Bulow, D. and A. Sorensen, 1993. Gender and contract farming: Tea outgrower scheme in Kenya. Rev. Afr. Political Econ., 56: 38-52.

Vera-Tascona, E., J.A. Gomez-Limon, E. Moyano and F. Garrido, 2008. Factors determining citizen's attitude towards agri-environmental property right. Environ. Res. Econ., 41: 541-561. DOI: 10.1007/s10640-008-9209-9 